\title{
Frequency of diabetic retinopathy in patients of acute ST elevated myocardial infarction (STEMI).
}

1. MBBS

Registrar Cardiology

Kuwait Teaching Hospital, Peshawar.

2. MBBS, FCPS (Cardiology)

Assistant Professor Cardiology

Kuwait Teaching Hospital, Peshawar.

3. MBBS, FCPS (Cardiology) District Cardiologist DHQ Hospital Landi Kotal, KPK.

4. MBBS, FCPS (Cardiology)

Assistant Professor Cardiology

Mardan Medical Complex, Mardan

5. MBBS,

FCPS-II (Trained in Cardiology)

Medical Officer Cardiology

Kuwait Teaching Hospital, Peshawar.

Correspondences Address:

Dr. Syed Tahir Shah

Department of Cardiology

Kuwait Teaching Hospital, Peshawar.

House \#146, Street \# 7, Sector F7,

Phase 6, Hayatabad, Peshawar.

drtshah80@gmail.com

Article received on:

19/10/2020

Accepted for publication:

$25 / 12 / 2020$

\section{Sanaullah1, Syed Tahir Shah², Abdul Salar Khan ${ }^{3}$, Noor ul Hadi', Naveed Ahmad ${ }^{5}$}

ABSTRACT... Objective: To determine the frequency of diabetic retinopathy in patients of acute ST elevated Myocardial Infarction (STEMI) in our population. Study Design: Cross Sectional study. Setting: Department of Cardiology, Lady Reading Hospital, Peshawar. Period: $20^{\text {th }}$ November 2018 to $19^{\text {th }}$ May 2019. Material \& Methods: Detailed history was taken and previous records were reviewed to look for diagnosis of DM, followed by complete examination and investigations including FBC, LFTs, RFTs, ECG and echo to fulfill exclusion criteria. Fundoscopy was performed by two experienced cardiology trainees with riester ophthalmoscope. Consensus was made on ophthalmoscopy findings regarding the presence or absence of Diabetic Retinopathy (DR). Results: In this study a total of 189 patients were observed. Mean age was 43 years with $S D \pm 11.23$. Sixty six percent patients were male while $34 \%$ patients were female. More over $5 \%$ patients had diabetic retinopathy while $95 \%$ patients did not have diabetic retinopathy. Conclusion: Our study concludes that the frequency of diabetic retinopathy was $5 \%$ in patients of acute ST elevated MI in our population.

Key word: $\quad$ Acute, Coronaryartey Disease, Diabetic Retinopathy, ST Elevated MI.

Article Citation: Sanaullah, Shah ST, Khan AS, Noor ul Hadi, Ahmad N. Frequency of diabetic retinopathy in patients of acute ST elevated myocardial infarction (STEMI). Professional Med J 2021; 28(7):1002-1007. https://doi.org/10.29309/TPMJ/2021.28.07.6166

\section{INTRODUCTION}

Coronary artery disease (CAD) is a leading cause of mortality in patients with diabetes both type I and type II. ${ }^{1-3}$ While macro vascular disease is the primary pathogenic mechanism underlying CAD in the general population, microvascular disease may play a prominent role in CAD development in diabetic individuals. ${ }^{4-9}$

Diabetic retinopathy (DR) is one of the important and lethal micro vascular complication of both types of diabetes. DR incidence and progression is linked to increased blood glucose level. In the United Kingdom Diabetes Prospective Study, good blood pressure control in isolation was associated with reduction in DR progression and loss of vision in type 2 diabetics patients. ${ }^{10}$ Dyslipidemia as well is linked to increased in DR development regardless of hyperglycemic status of patients without concrete evidence in some of epidemiological study. ${ }^{11-14}$ Result of recent research provides evidence that retinopathy is one of initial and common sign of vascular complications and is closely linked to the development of coronary artery disease (CAD)..$^{15,16}$ Coronary atherosclerosis (CAS), manifest as an initial and subclinical manifestation of $C A D$, begins with the inflammatory activation of endothelial cells and the deposition of cells and extracellular matrix within the inner vessel wall, resulting in intimal thickening followed by accumulation of lipid and formation of thin fibrous cap resulting in soft plaque. ${ }^{17,18}$ Calcified plaque formation start late in the course of development of atherosclerosis. Ischemia results when artery lumen is narrowed more than $70 \%$ due to increased intimal thickening. Therefore, accelerated CAS is one of the important cause of CAD in type II diabetes, which accounts for the higher rates of complications.

Diabetic retinopathy is a one of the important complication of microvascular disease in T2DM. The presence of DR along with increased risk of 
CAD could not be clearly defined. Few studies have provided inconclusive results regarding the association of retinopathy with CAD risk in diabetic patients. ${ }^{17-23}$ However, in a number of studies conducted in Taiwan, Europe, America, Turkey the frequency of coronary artery disease in patients with diabetic retinopathy has been $70 \%, 71.5 \%, 73.9 \%$ and $81 \% .{ }^{24-28}$ On the other hand, Fawzia et $\mathrm{al}^{29}$ reported $80 \%$ stenotic CAD in patients with DR. Gimeno-Orna et $\mathrm{al}^{30}$ also elaborated $\mathrm{DR}$ as a risk factor for CAD. In another study forty percent diabetic patient with CAD had DR as well, which was confirmed by non-mydriatic fundus images. ${ }^{31}$

The idea of doing this study came to us after carefully reviewing the literature where we found that still little evidence is available regarding frequency of diabetic retinopathy in patients of acute ST elevated MI in our population. We want to determine the frequency of diabetic retinopathy in patients of acute ST elevated MI in our population in this study. Once the frequency will be known, which is not known in our population yet we will be able to identify the high risk population for AMI just by looking for diabetic cardiovascular events.

\section{MATERIAL \& METHODS}

This cross-sectional study was conducted at Department of Cardiology, Lady Reading Hospital, Peshawar from 20 $0^{\text {th }}$ November 2018 to19 ${ }^{\text {th }}$ May 2019. Sample size was calculated as 189, using WHO sample size calculator and keeping $40 \%$ prevalence of DR in patients with $\mathrm{CAD}^{31}$, at $95 \%$ confidence interval and $7 \%$ margin of error. Sampling Technique was Nonprobability consecutive sampling. The study was conducted after approval from hospitals ethical committee (Ref. No. 34/LRH). All patients meeting the inclusion criteria were included in the study through OPD or Emergency Department. The purpose and benefits of the study was explained to all patients and an informed consent was taken.

Patients of both genders, aged 20 to 60 years, with history of diagnosed diabetes mellitus for at least seven years presenting to cardiology unit with acute ST elevated MI within 24 hours of diagnosis of STEMI were in included in the study.
Detailed history was taken and previous records was reviewed followed by complete examination and investigations including FBC, LFTs, RFTs, ECG and echo cardiography to fulfill exclusion criteria. Patients were excluded if they have ; Previous history of acute coronary syndrome, angioplasty or bypass surgery, congenital heart disease, cardiomyopathy, heart failure, having hypertensive retinopathy, patients with cataracts or history of cataract surgery, patients with other retinal diseases like pan retinitis, maculopathies etc, patients with conjunctivitis and other conjunctival diseases like pterygium etc. patients with history of retinal photo coagulation. The above variables if included will result in confounder's bias.

Fundoscopy was performed by two experienced cardiology trainees with RIESTER ophthalmoscope. Consensus was made on ophthalmoscopy findings regarding the presence or absence of DR. All the above mentioned information was recorded to a predesigned proforma. Strict inclusion and exclusion criteria had followed to minimize bias. Patients were labelled as having DR if they have, micro aneurysms, Dot and blot hemorrhages, venous beading, and cotton wool spots in retina on fundoscopy. If these features are not present patient was not be having DR. Patients who are already diagnosed cases of diabetes mellitus were included in study. Patients were labelled as having diabetes mellitus if they had a fasting blood sugar level of $126 \mathrm{mg} / \mathrm{dl}$ or more at the time of diagnosis of DM or random blood sugar level of $200 \mathrm{mg} / \mathrm{dl}$ or more at the time of diagnosis of DM. For this purpose, records were reviewed of every patient. Patient were labeled as Acute ST elevated myocardial infarction if they have central, retro- sternal, constant throbbing chest pain for more than four hours with ST segment elevation of more than $1 \mathrm{~mm}$ in limb leads and $2 \mathrm{~mm}$ in chest leads in ECG.

The collected data was stored and analyzed in SPSS version 20 for windows. Continuous data like age, weight, height, BMl were calculated as mean and standard deviation. Categorical variables like gender, smoking, HTN, type of MI 
and diabetic retinopathy were represented as frequencies and percentage. diabetic retinopathy were stratified for age, gender, smoking, HTN, BMI, type of MI. Post stratification chi-square test was applied in which P-value $\leq 0.05$ was taken as significant. All results were presented in the form of tables, graphs, and charts.

\section{RESULTS}

In this study age distribution among 189 patients was analyzed as $57(30 \%)$ patients were in age range 20-40 years, 132(70\%) patients were in age range 41-60 years. Mean age was 43 years with SD \pm 11.23 . Gender distribution among 189 patients was analyzed as $125(66 \%)$ patients were male while 64(34\%) patients were female. Among 189 patients $155(82 \%)$ were hypertensive while $34(18 \%)$ patients were not hypertensive. Among 189 patients $79(42 \%)$ patients were smokers while $110(58 \%)$ patients were not smokers. Among 189 patients $123(65 \%)$ patients had anterior MI while $66(35 \%)$ patients had Inferior MI. Among subjects $119(63 \%)$ patients had $\mathrm{BMl}<30 \mathrm{Kg} / \mathrm{m} 2$ while $70(37 \%)$ patients had $\mathrm{BMI}<30 \mathrm{Kg} / \mathrm{m}^{2}$ as shown in Table-I.

Status of diabetic retinopathy among 189 patients had was analyzed as $9(5 \%)$ patients had diabetic retinopathy while $180(95 \%)$ patients didn't had diabetic retinopathy (Table-II).

Stratification of diabetic retinopathy with respect to age, gender, smoking, HTN, BMI, type of $\mathrm{MI}$ is given in Table-III.

\section{DISCUSSION}

Acute myocardial infarction (AMI) is one of the most common medical emergencies worldwide with significant morbidity and mortality. At present, it affects 3 million individuals annually. The adversity of AMI is reduced in recent years due to better understanding of Pathophysiology and advancement in preventive care, diagnostic capability and therapies for AMI with gross reduction in mortality rate from 25 to 30 percent in 1960 s to current 6 percent. Cardiac arrhythmias and mechanical complications that result in cardiogenic shock are important causes of mortality in AMI.

\begin{tabular}{|c|c|c|c|}
\hline \multicolumn{2}{|c|}{ Variables } & Frequency & Percentage \\
\hline \multicolumn{2}{|c|}{$\begin{array}{l}\text { Age }(\text { mean }=43 \pm 11.23) \\
20-40 \text { year } \\
41-60 \text { year }\end{array}$} & $\begin{array}{c}57 \\
132\end{array}$ & $\begin{array}{l}30 \% \\
70 \%\end{array}$ \\
\hline \multicolumn{2}{|l|}{$\begin{array}{l}\text { Gender } \\
\text { Male } \\
\text { Female }\end{array}$} & $\begin{array}{c}125 \\
64\end{array}$ & $\begin{array}{l}66 \% \\
34 \%\end{array}$ \\
\hline \multicolumn{2}{|l|}{$\begin{array}{l}\text { Hypertension } \\
\text { Yes }\end{array}$} & $\begin{array}{c}155 \\
34\end{array}$ & $\begin{array}{l}82 \% \\
18 \%\end{array}$ \\
\hline \multicolumn{2}{|l|}{ Smoking } & $\begin{array}{c}79 \\
110\end{array}$ & $\begin{array}{l}42 \% \\
58 \%\end{array}$ \\
\hline \multicolumn{2}{|l|}{$\begin{array}{l}\text { Type of STEMI } \\
\text { Anterior } \\
\text { Inferior }\end{array}$} & $\begin{array}{c}123 \\
66\end{array}$ & $\begin{array}{l}65 \% \\
35 \%\end{array}$ \\
\hline \multicolumn{2}{|c|}{$\begin{array}{l}\text { BMI } \\
\text { (mean=28 Kg/m² } \pm 11.23) \\
<30 \\
>30\end{array}$} & $\begin{array}{c}119 \\
70\end{array}$ & $\begin{array}{l}63 \% \\
37 \%\end{array}$ \\
\hline \multicolumn{4}{|c|}{ Table-I. Baseline Characteristics $(n=189)$. } \\
\hline \multicolumn{2}{|c|}{$\begin{array}{c}\text { Diabetic } \\
\text { Retinopathy }\end{array}$} & Frequency & Percentage \\
\hline \multicolumn{2}{|l|}{ Yes } & 9 & $5 \%$ \\
\hline \multicolumn{2}{|l|}{ No } & 180 & $95 \%$ \\
\hline \multicolumn{2}{|l|}{ Total } & 189 & $100 \%$ \\
\hline \multicolumn{4}{|c|}{ Table-II. Diabetic Retinopathy. } \\
\hline \multirow{2}{*}{ Variables } & \multicolumn{2}{|c|}{ Diabetic Retinopathy } & \multirow{2}{*}{ P-Value } \\
\hline & Present & Absent & \\
\hline $\begin{array}{l}\text { Age } \\
20-40 \\
41-60\end{array}$ & $\begin{array}{l}3 \\
6\end{array}$ & $\begin{array}{c}54 \\
126\end{array}$ & 0.8316 \\
\hline $\begin{array}{l}\text { Gender } \\
\text { Male } \\
\text { Female }\end{array}$ & $\begin{array}{l}6 \\
3\end{array}$ & $\begin{array}{c}119 \\
61\end{array}$ & 0.9725 \\
\hline $\begin{array}{l}\text { Hypertension } \\
\text { Yes } \\
\text { No }\end{array}$ & $\begin{array}{c}7 \\
148\end{array}$ & $\begin{array}{c}2 \\
32\end{array}$ & 0.7347 \\
\hline $\begin{array}{l}\text { Smoking } \\
\text { Yes } \\
\text { No }\end{array}$ & $\begin{array}{l}4 \\
5\end{array}$ & $\begin{array}{c}75 \\
105\end{array}$ & 0.8690 \\
\hline $\begin{array}{l}\text { STEMI } \\
\text { Anterior } \\
\text { Inferior }\end{array}$ & $\begin{array}{l}6 \\
3\end{array}$ & $\begin{array}{c}117 \\
63\end{array}$ & 0.9184 \\
\hline $\begin{array}{l}\text { BMI }\left(\mathrm{kg} / \mathrm{m}^{2}\right) \\
<30 \\
>30\end{array}$ & $\begin{array}{l}6 \\
3\end{array}$ & $\begin{array}{c}113 \\
67\end{array}$ & 0.8136 \\
\hline \multicolumn{4}{|c|}{$\begin{array}{c}\text { Table-III. Stratification of diabetic retinopathy w.r.t } \\
\text { various variables }(n=189) \text {. } \\
\text { Chi square test was applied in which } P \text { value }\end{array}$} \\
\hline
\end{tabular}


Our study shows mean age was 43 years with $\mathrm{SD} \pm 11.23$. Sixty six percent patients were male while $34 \%$ patients were female. More over $5 \%$ patients had diabetic retinopathy while $95 \%$ patients didn't had diabetic retinopathy.

Similar findings were observed in other studies conducted by Rong $\mathrm{J}$ et $\mathrm{al}^{24}$, Pradeepa $\mathrm{R}$ et $\mathrm{al}^{25}$ and Xie $\mathrm{J}^{26}$ in which the frequency of CAD in patients with DR has been 70\%, 71.5\%, 73.9\% and $81 \%$. On the other hand, Fawzia et $a^{29}$ reported $80 \%$ stenotic CAD in patients with DR. with Gimeno-Orna et $\mathrm{al}^{30}$ also elaborated DR as a risk factor for CAD. In another study forty percent diabetic patient with CAD had DR as well, which was confirmed by non-mydriatic fundus images. ${ }^{31}$

In a study conducted by Raj BK et $\mathrm{al}^{32}$, they had mentioned that the presence of microvascular diabetic complications was more with nephropathy then with retinopathy (62 vs 58\%). Neuropathy was not documented. Approximately, thirty two (32\%) of patients were having no microvascular complications. Other macrovascular diabetic complications were not documented. Twenty four percent $(24 \%)$ of ACS patient developed hypotension only as a complication while $76 \%$ had no complication at all. None of the patient died. Systolic dysfunction was present in eighty two percent (82\%) and diastolic dysfunction in $66 \%$. Sixty two patients had very high glycaled hemoglobin level (i.e $\mathrm{HbA} 1 \mathrm{c}>7 \%$ ) while $32 \%$ of patients had their $\mathrm{HbA1c}$ level in the control range.

\section{CONCLUSION}

Our study concludes that the frequency of diabetic retinopathy was $5 \%$ in patients of acute ST elevated $\mathrm{MI}$ in our population.

\section{Copyright@ 25 Dec, 2020.}

\section{REFERENCES}

1. Gu K, Cowie CC, Harris MI. Diabetes and decline in heart disease mortality in US adults. JAMA. $1999 \mathrm{Apr}$ 14; 281(14):1291-7.

2. Kannel WB, McGee DL. Diabetes and cardiovascular disease: The Framingham study. JAMA. 1979 May 11; 241(19):2035-8.
3. Grundy SM, Benjamin IJ, Burke GL, Chait A, Eckel RH, Howard BV, Mitch W, Smith SC, Sowers JR. Diabetes and cardiovascular disease. Circulation. 1999 Sep 7; 100(10):1134-46.

4. Factor SM, Okun EM, Minase T. Capillary microaneurysms in the human diabetic heart. NEJM. 1980 Feb 14; 302(7):384-8.

5. Di Carli MF, Janisse J, Ager J, Grunberger G. Role of chronic hyperglycemia in the pathogenesis of coronary microvascular dysfunction in diabetes. JACC. 2003 Apr 16; 41(8):1387-93.

6. Miura H, Wachtel RE, Loberiza FR, Saito T, Miura $M$, Nicolosi $A C$, et al. Diabetes mellitus impairs vasodilation to hypoxia in human coronary arterioles. Circulation research. 2003 Feb 7; 92(2):151-8.

7. Li H, Gutterman DD, Rusch NJ, Bubolz A, Liu Y. Nitration and functional loss of voltage-gated $\mathrm{K}+$ channels in rat coronary micro vessels exposed to high glucose. Diabetes. 2004 Sep 1; 53(9):2436-42.

8. Pitkänen OP, Nuutila P, Raitakari OT, Rönnemaa T, Koskinen $\mathrm{PJ}$, lida $\mathrm{H}$, et al. Coronary flow reserve is reduced in young men with IDDM. Diabetes. $1998 \mathrm{Feb}$ $1 ; 47(2): 248-54$.

9. Di Carli MF, Bianco-Batlles D, Landa ME, Kazmers A, Groehn $\mathrm{H}$, Muzik $\mathrm{O}$, et al. Effects of autonomic neuropathy on coronary blood flow in patients with diabetes mellitus. Circulation. 1999 Aug 24; $100(8): 813-9$.

10. UK Prospective Diabetes Study Group. Tight blood pressure control and risk of macrovascular and microvascular complications in type 2 diabetes: UKPDS 38. BMJ. 1998 Sep 12; 317(7160):703.

11. Klein BE, Moss SE, Klein R, Surawicz TS. The Wisconsin Epidemiologic Study of Diabetic Retinopathy: XIII. Relationship of serum cholesterol to retinopathy and hard exudate. Ophthalmology. 1991 Aug 1; 98(8):12615 .

12. Chew EY, Klein ML, Ferris FL, Remaley NA, Murphy $\mathrm{RP}$, Chantry $\mathrm{K}$, et al. Association of elevated serum lipid levels with retinal hard exudate in diabetic retinopathy: Early treatment diabetic retinopathy study (ETDRS) report 22. Archives of ophthalmology. 1996 Sep 1; 114(9):1079-84.

13. Ferris FL, Chew EY, Hoogwerf BJ, Early treatment diabetic retinopathy study research group. Serum lipids and diabetic retinopathy. Diabetes Care. 1996 Nov $1 ; 19(11): 1291-3$ 
14. Keech AC, Mitchell P, Summanen PA, O'day J, Davis TM, Moffitt MS, et al. Effect of fenofibrate on the need for laser treatment for diabetic retinopathy (FIELD study): A randomized controlled trial. The Lancet. 2007 Nov 17; 370(9600):1687-97.

15. Norgaz T, Hobikoglu G, Aksu H, Guveli A, Aksoy S, Ozer $O$,et al. Retinopathy is related to the angiographically detected severity and extent of coronary artery disease in patients with type 2 diabetes mellitus. International heart journal. 2005; 46(4):639-46.

16. Wong TY, Klein R, Couper DJ, Cooper LS, Shahar E, Hubbard LD, et al. The prevalence and risk factors of retinal microvascular abnormalities in older persons: The cardiovascular health study. Ophthalmology 2003; 110: 658-666.

17. Miettinen $\mathrm{H}$, Haffner $\mathrm{SM}$, Lehto $\mathrm{S}$, Rönnemaa $\mathrm{T}$, Pyörälà K, Laakso M. Retinopathy predicts coronary heart disease events in NIDDM patients. Diabetes Care. 1996 Dec $1 ; 19(12): 1445-8$.

18. Faglia E, Favales F, Calia P, Paleari F, Segalini G, Gamba $P L$, et al. Cardiac events in 735 type 2 diabetic patients who underwent screening for unknown asymptomatic coronary heart disease. Diabetes Care. 2002 Nov 1; 25(11):2032-6.

19. Soedamah-Muthu SS, Chaturvedi N, Witte DR, Stevens LK, Porta M, Fuller JH. Relationship between risk factors and mortality in type 1 diabetic patients in Europe. Diabetes Care. 2008 Jul 1; 31(7):1360-6.

20. Targher G, Bertolini L, Tessari R, Zenari L, Arcaro G. Retinopathy predicts future cardiovascular events among type 2 diabetic patients. Diabetes care. 2006 May $1 ; 29(5): 1178$.

21. Turner RC, Millns H, Neil HA, Stratton IM, Manley SE, Matthews DR, Holman RR. Risk factors for coronary artery disease in non-insulin dependent diabetes mellitus: United Kingdom Prospective Diabetes Study (UKPDS: 23). Bmj. 1998 Mar 14; 316(7134):8238.

22. Klein R, Klein BE, Moss SE, Cruickshanks KJ. Association of ocular disease and mortality in a diabetic population. Archives of Ophthalmology. 1999 Nov $1 ; 117(11): 1487-95$.

23. Juutilainen A, Lehto S, Rönnemaa T, Pyörälä K, Laakso M. Retinopathy predicts cardiovascular mortality in type 2 diabetic men and women. Diabetes care. 2007 Feb 1; 30(2):292-9.
24. Rong J, Yu CQ, Yang $\mathrm{P}$, Chen J. Association of retinopathy with coronary atherosclerosis determined by coronary 64-slice multidetector computed tomography angiography in type 2 diabetes. Diabetes and Vascular Disease Research. 2013 Mar; 10(2):161-8.

25. Pradeepa R, Surendar J, Indulekha K, Chella S, Anjana RM, Mohan V. Relationship of diabetic retinopathy with coronary artery disease in Asian Indians with type 2 diabetes: The Chennai Urban Rural Epidemiology Study (CURES) Eye Study-3. Diabetes technology \& therapeutics. 2015 Feb 1; 17(2):112-8.

26. Xie J, Ikram MK, Cotch MF, Klein B, Varma R, Shaw JE, et al. Association of diabetic macular edema and proliferative diabetic retinopathy with cardiovascular disease: A systematic review and meta-analysis. JAMA ophthalmology. 2017 Jun 1.

27. Bello NA, Pfeffer MA, Skali H, McGill JB, Rossert J, Olson KA, et al. Retinopathy and clinical outcomes in patients with type 2 diabetes mellitus, chronic kidney disease, and anemia. BMJ Open Diabetes Research and Care. 2014 Apr 1; 2(1):e000011.

28. De Ferranti SD, De Boer IH, Fonseca V, Fox CS, Golden $\mathrm{SH}$, Lavie CJ, et al. Type 1 diabetes mellitus and cardiovascular disease. Circulation. 2014 Sep 23; 130(13):1110-30.

29. El Demerdash F, Refaie W, Allakany R, Tantawy S, Dawood E. Diabetic retinopathy: $A$ predictor of coronary artery disease. The Egyptian Heart Journal. 2012 Jun $1 ;$ 64(2):63-8.

30. Ohno T, Kinoshita O, Fujita H, Kato S, Hirose A, Sigeeda $\mathrm{T}$, et al. Detecting occult coronary artery disease followed by early coronary artery bypass surgery in patients with diabetic retinopathy: Report from a diabetic retinocoronary clinic. The Journal of thoracic and cardiovascular surgery. 2010 Jan 1; 139(1):92-7.

31. Ohtomo K, Shigeeda T, Hirose A, Ohno T, Kinoshita $\mathrm{O}$, Fujita $\mathrm{H}$, et al. Frequency of diabetic retinopathy and related factors in patients with diabetes having coronary artery disease. Diabetes research and clinical practice. 2016 Aug; 118:154.

32. Raj BK, Sivachandran G. A study on clinical profile of acute coronary syndrome in type 2 diabetes mellitus patients with relevance to HbA1c. IAIM, 2018; 5(8): 1-8. 


\section{AUTHORSHIP AND CONTRIBUTION DECLARATION}

\begin{tabular}{|c|c|c|c|}
\hline Sr. \# & Author(s) Full Name & Contribution to the paper & Author(s) Signature \\
\hline 1 & Sanaullah & $\begin{array}{l}\text { Concept \& Design of study, Revising } \\
\text { critically, Final approval of version. }\end{array}$ & \\
\hline 2 & Syed Tahir Shah & $\begin{array}{l}\text { Drafting, Data analysis, Revising } \\
\text { critically. }\end{array}$ & \\
\hline 3 & Abdul Salar Khan & Drafting, Data analysis. & \\
\hline 4 & Noor ul Hadi & Data analysis, Revising critically. & \\
\hline 5 & Naveed Ahmad & Drafting, Data analysis. & then \\
\hline
\end{tabular}

